\title{
EU Integration and Harmonisation of Personal Income Taxation
}

\author{
Tomasz Wołowiec ${ }^{1}$, Janusz Soboń ${ }^{2}$
}

ABSTRACT In the process of furthering EU integration little attention was given to the role of income taxes. Multiple income tax systems exist across the Union and their differentiation negatively impacts the European labour market, investments and savings, inhibiting economic growth. Individual nations have little motivation to harmonise as they can engage in tax rate competition and income taxes are interwoven with social security systems that make any attempts at reform extremely complex and politically unpopular. Much of current harmonisation is "silent", paralegal, and occurs in response to market forces rather than following a formal plan and through intergovernmental cooperation.

Key words: EU integration, tax harmonisation, personal income taxation, tax system differentiation

\section{JEL Classification: F15, H20, H24}

${ }^{1}$ Institute for Financial Research and Analyses, University of Information Technology and Management in Rzeszów, Poland ${ }^{2}$ Wyższa Szkoła Biznesu-National Louis University in Nowy Sącz, Poland

\section{Introduction}

The idea of a single economic and currency area is based on enabling the free flow of goods, capital and people (labour) while subject to a single currency regime. The idea deals effectively with currency risk, trade barriers, assures easy access to the labour market and provides opportunities for investing in all member states.

Full economic integration requires consideration of taxes as an important factor in the furthering of integration processes, since EU member states are tax nations, e.g. countries where budgetary incomes come primarily from taxation. EU member state tax systems are strongly diversified, due to individual developmental paths shaped by national history of various lengths, civilisational development, culture, value systems, social and economic policy, which also define the state's current financial needs. Even in a single state, taxes cannot remain neutral towards economic and social processes. Therefore, the challenge faced by EU cre-

Corespondence concerning to this article should be addressed to:wolowiec@wsb-nlu.edu.pl ators was not the outright neutralisation of the impact that taxes had on the integration process, rather they worked towards limiting the negative consequences of overly diversified national tax systems. Gradual, longterm harmonisation emerged as a continent-wide process. During the development of the Treaty of Rome it was decided that, to assure a common market, it was enough to harmonise indirect taxes and remove trade barriers as they were the prime inhibitors to the flow of goods and services. The harmonisation of direct (income) taxes was not considered as they were seen as not significantly affecting the single internal market. Problems tied to direct taxation became visible as integration proceeded, the EU grew, its citizens began to migrate, multinational enterprises increased in size and scope and their financial flows (capital and profit transfers between headquarters and subsidiaries in different EU countries) became seriously affected (Mintz, 2004: 221-234).

Because the Euro zone is relatively young and many integrative processes haven't reached their end, we can look for analogies elsewhere: of nations that have a sin- 

dance with the current state of integration. On the other hand, the response to increasing economic integration and tax competition in Europe cannot be simply tax harmonization. As emphasized by the literature, in certain cases such a development would have negative welfare effects for some members and does not fully address the fiscal aspects of the integration process. However, it lays the foundation for closer co-operation in the tax field and paves the way for fiscal integration in the EU (Vogitzoglou, 2004: 119-125).

\section{Differentiation of personal income taxation across the Union}

Personal income taxes are strongly differentiated in EU member states in terms of setting the size of tax brackets and taxable income level, where the differentiation focuses on different perceptions of what should constitute the basis of taxation, different tax scales, tax credits and allowable deductions. This process erodes the tax base (EC, 2008; OECD, 2006; IBFD, 2009). Most nations have a tax-free income that represents the expenditure for minimal biological survival. Tax credits and allowable deductions are not only differentiated country by country but also are subject to fluctuations due to a changing social and economic national environment, the preferences of ruling political parties, phase of the business cycle (Zee, 2005).

EU member states have to consider the taxpayer's ability to pay (occurring jointly, separately or as selected elements) when creating different components of Personal Income Tax (PIT) policies, which may include:

- Setting a tax-free level of income that is offered to an unemployed spouse (e.g. in Slovakia), offered for each child being supported by the parents (e.g. Belgium, Czech Republic, Estonia, Holland, Germany, France, Greece, Slovenia, Lithuania).

- Joint taxation of married couples (e.g. in Ireland, where we can find separate tax scales for single taxpayers and married couples).

- Specific and unique taxation of family income (France operates family quotient taxation that considers the number of children in the family).

- Constructions that permit the deduction of certain costs incurred while bringing up children (e.g. France) or even when supporting the family (e.g. Germany).

- Size and breadth of tax brackets.
- Systems defining the permissible and deductible expenses.

- Systems of preferences depending on the family's situation.

When analysing tax credits and allowable deductions present in EU member states (as subject-specific credits, deductions from tax and tax base), four main categories can be identified:

1. Compensation-type preferences: equivalency and compensation payouts for used tools, clothing, travel costs, refunding travel-to-work expenditures, etc.

2. Social-type preferences: deductions for social support for foster families, support for foster families, war veterans, victims of crime, handicapped, elderly, etc.

3. Stimulation-type (economic) preferences: aimed at stimulating the taxpayer to engage in specific activities or modifying his behaviours. We can include deductions for housing (development and renovation), preferential treatment of savings, purchasing of stocks and bonds, educating children, professional development, health expenditures and retirement fund investments.

4. Differentiated incomes, for example gambling wins, research grants, rewards for scientific activity, scholarships, contributions towards professional associations, etc.

So we should expect rational individuals to pursue taxbenefit-seeking mobility of labour. In reality the extensiveness of this mobility would be dependent not only on "tax wedge" levels (share that PIT and national insurance consume from gross income) but also on level of wages, gross income levels, the nature of the labour market, quality of public services and infrastructure. Such rent-seeking tax migration would lead to increasing the supply of qualified labour in the market of the accepting country (with a competitive tax system and good labour market) while worsening the labour market situation in the country from which a worker has departed. As a result, countries keen to gain valuable workers could consider setting competitive tax rates to lure in new employees who would migrate and stay, contributing to national economic growth and pay their taxes in the accepting state. In this context harmonisation would be seen as a process of equalisation of life and employment conditions that would reduce the need for "tax wedge" oriented analyses by workers. 


\section{Downward trend in top personal income tax rates since 1995}

Currently, the top personal income tax (PIT) rate (2) amounts to $37.5 \%$, on average, in the EU. This rate varies very substantially within the Union, ranging from a minimum of $10 \%$ in Bulgaria to a maximum of 56.4 in Sweden, as Denmark, which levied the highest PIT maximum rate until last year, has cut it to $51.5 \%$ (Taxation Trends 2009). As a rule, as has been the case in recent years, the new Member States, with the exception of Slovenia and Hungary, display below-average top rates, while the highest rates are typical of Member States with the most elevated overall tax ratios, such as the Nordic countries, although the Netherlands show the third highest top personal income rate while ranking 15 th in terms of the tax ratio (excluding social security contributions). The lowest rates are found in Bulgaria, the Czech Republic and Lithuania. In the latter two the overall tax ratio (excluding SSCs) is among the lowest in the Union, which is however not really the case in Bulgaria (Taxation Trends, 2009).

For the first time in several years, the top PIT rate has increased, on average, in 2010, despite the sizeable Danish cut, as several EU Member States enacted increases (the UK introduced a new 50\% rate, ten points higher than the previous maximum, but Greece and Latvia too hiked their top rates). It is plausible to attribute this reversal to the effect of the economic and financial crisis as until this year, there had been a clear, steady and widespread downward trend in the top rate. From 1995 to 2009, almost all EU Member States cut their top rate, with only three keeping it unchanged (Malta, Austria and The United Kingdom) and one (Portugal) increasing it slightly. Even taking into account the subsequent 0.4 average rate increase in 2010, all in all, the EU-27 average has gone down by 9.9 percentage points since 1995 , accelerating after 2000. The post-2000 acceleration is most noticeable in the Central and Eastern European countries, with the biggest cuts having taken place in four countries that adopted flat rate systems, Bulgaria ( -30.0 percentage points), the Czech Republic (-17.0), Romania (-24.0) and Slovakia (-23.0); the acceleration was, however, visible also in the old EU Member States (Taxation Trends, 2008). One should nevertheless note that the increase in the average in 2010 is due to sizeable hikes in a small number of countries, while the overwhelm- ing majority of Member States, including several that have been amongst the strongest hit by the crisis, have kept their top PIT rate constant. Lower PIT top rates do not necessarily imply a trend towards lower PIT revenues, because in systems with several tax brackets, the percentage of taxpayers taxed under the highest rate is typically quite limited. In addition, changes in the tax threshold can have important effects on the tax liability, even at unchanged rates; for example, in 2009, Austria increased the threshold for the top 50\% bracket by around $18 \%$, reducing the tax liability, but this is not visible when looking only at the rate. Several countries, however, have moved towards systems with fewer brackets, or to flat rate systems, which are characterised by a single PIT tax rate, so that any reduction is immediately reflected in the tax revenue. Furthermore, cuts in the top PIT rate typically do not occur in isolation, but are part of balanced packages which may include tax reductions for lower-income taxpayers or measures to offset the loss of revenue.

As of 2010, these Member States comprise Bulgaria, the Czech Republic, Estonia, Latvia, Lithuania, Romania, and Slovakia. As can be seen, all flat rate systems in the EU were introduced by new Member States, the latest two being Bulgaria and the Czech Republic in 2008. All of these show a lower than average revenue from the PIT, although the distance from the EU mean value is not very marked for the three Baltic States (Taxation Trends, 2009: 20).

\section{Theoretical foundations of income tax harmonisation}

Income taxes are characterised by a clear link between the taxpayer's situation (income, wealth) and the tax burden placed upon him (Alworth and Arachi, 2008). As such, income taxes can have a negative impact, be de-motivating, as the tax will inhibit income-generating and investment activity and that will negatively impact the speed of economic growth (Caroll and HoltzEakin, 2000; Widman, 2001). This means that not only the sheer size of the tax burden is important, but also we have to consider the entire structure of the tax system, each tax and the definition of tax scales/brackets (Meghir and Philips, 2008; Sabrinova, Buttrick and Duncan, 2008).

Inadequacies of tax theories combined with a polarisation of opinion maker positions concerning per- 
sonal income taxes impact even the microeconomic approach, where it should be easy to establish a causal link between the tax burden, tax scale and the taxpayer's economic situation and resulting decisions. This is a result of multiple interacting factors affecting the taxpayer; therefore isolation of the tax factor is difficult, if we bypass highly abstract analyses. The situation becomes even more complicated when the subject of analysis becomes the impact of a given tax on a specific group of taxpayers or of a specific tax on the entire economy (e.g. automatic stabiliser theory) (KMPG, 2008). We have to add the fact that income taxes are only part of a wider burden, since they are combined with national security contributions (social insurance) and often it is those social security contributions that are modified to increase governmental revenues, while maintaining an illusion of tax rate stability.

The complexity of tax analysis from the perspective of income tax impacting a taxpayer and the wider economy increases when we take the analysis beyond the borders of a single country. Tax relations become increasingly complex, and the impact of particular income taxation becomes extremely difficult to evaluate, quantify. This statement can be taken as the explanation for existing tax controversies: tax harmonisation between nations versus the freedom to engage in unlimited tax competition.

A theoretical analysis of the effects of tax differentiation can occur on several axes, including:

- Impact of PIT on costs of labour. High taxes increase labour costs since after-tax income (disposable) is low and thus causes pay-increase demands from the workers and this in turn complicates the company's competitive standing and affects its profitability (when compared to companies operating in other, more beneficial tax environments).

- Taxes as a burden. They force a defensive response from the taxpayer in the form of seeking opportunities to transfer the burden onto other entities. Centuries long observation of taxpayer reactions to tax burdens show that, even if desirable, burden shifting is much easier in the case of indirect taxes than direct ones (in this case the most common technique involves limiting economic activity) (James, Nobes, 1995).

- Tax burden transferability is different for employees and employers. Increased labour costs will af- fect production costs and this affects final product/ service prices. Opportunities open to the employer will depend on the type of the good/service under taxation and the state of the market (competition), which is defined through elasticity of demand. Inelasticity of demand for a good will assure easier transfer of tax burdens by the employer onto the client. A second possible reaction is to transfer the burden onto the employees by lowering their wages. Opportunities here will be defined by the current state of the labour market, its openness, level of unemployment and elasticity of labour supply.

- Measuring the transferability of the tax burden. The process is difficult even in the case of a closed economy because the effects of increasing taxes can be hidden in prices, non-wage production costs, producer profitability. These difficulties are multiplied in an open economy where the mechanism of transferring the tax burden affects the society and economy of a different nation. In a theoretical sense, "tax dumping"1 leads to a redistribution of income between different societies as it assures that part of the income is transferred to nations with lower taxes through transfer pricing or through the transfer of company operations to locations with favourable tax regimes. The impact on nations not operating "tax dumping" policies is a need to increase tax rates to maintain governmental revenues (for those taxpayers that remain) or reduce governmental expenditures (politically difficult) or increase national debt (finding lenders willing to fund continued expenditures) ${ }^{2}$.

In the era of internationalisation of economic relations and integration, the tax burden transfer mechanism becomes international, in terms of taxation on incomes, labour, economic activity, interest, capital returns, etc. Personal decisions regarding where to undertake paid employment (with the assumption that there are no restrictions on the movement of labour) will be affected by offered wages and required taxes. Income migration therefore becomes natural as people gravitate towards locations where incomes and taxes are the most beneficial. Of course, changing the location of activity is much easier for an employee than for an employer and entrepreneur as the latter two have to adapt to the requirements of the host country to where their activity is being transferred (for entire company 
or its part, subsidiary). Both labour and capital would therefore benefit from tax harmonisation as it would simplify operations and create a more balanced environment that would reduce the need for mobility oriented purely on seeking tax benefits.

Both tax rate harmonisation and tax rate competitiveness require additional consideration of:

- Impact of PIT rate harmonisation upon the state budget and possible imbalance of public finances (harmonisation worsening national budgets, e.g. through downward integration of tax rates).

- Impact of labour mobility upon the nation's economy (income migration further enhanced by PIT rates).

- Impact of changes in the tax system, which affect the ratios of: indirect-direct taxes, CIT-PIT, when they are intended to draw in foreign investments.

In small open economies that seek new/additional capital resources these issues are further differentiated: in the case of transforming economies and developing nations their situation is much more difficult than of countries with a strong position within an economic grouping or the entire global economy.

Economic aims of tax harmonisation may be unachievable due to legal reasons, since a tax is not only an economic category but also a legal one, and its legal side is affected by:

- Relationship between national and Community law, and when considering the supremacy of EU law over national rules, many issues emerge (e.g. conflicting regulations, different interpretations).

- Problems of applying (and in what measures) unlimited tax duty ${ }^{3}$ in one country compared to applying unlimited tax duty in one country with a limited duty in the second country and, finally, how to apply unlimited tax duties in both countries.

- How to formulate and agree upon treaties on avoiding double taxation (not only achieving consensus between nations but also following local political patterns, taxation trends).

- Problems in whether to collect the tax in country of residence or non-residence and in what proportions.

\section{Legal foundations of harmonisation}

The notion of harmonising direct income taxes, especially on corporate and capital returns appeared in an early stage of Community creation. This was pursued although harmonisation was not included in the Treaty, whose creators focused instead on harmonisation of indirect taxes. Nonetheless, the Treaty contains Article 94, which calls for the harmonisation of legal regulations that directly impact the operations of the internal market. This can be seen as the beginning of efforts aimed at direct tax harmonisation (Szeląg, 2003: 91-96). Article 308 allows the Council, based on a request for the European Commission and after consulting with the EU Parliament, may undertake activities aimed at achieving an aim within the common market. This requires unanimous approval of all member states, which will be extremely difficult to achieve, seeing that personal income taxes are the most "political" of taxes and are a major fiscal tool for all EU nations.

The problem of taxing personal incomes and their impact on the free movement of labour and capital was only partially visible to the Union. Below is a list of documents in which the topic of taxing personal income appeared in various contexts and partial manner:

- Neumark Report, 1962;

- EU Commission Memorandum, 1967;

- EU Commission Memorandum, 1969;

White Book on the Creation of the Common Market, 1985 ;

- Ruding Report, 1992;

White Book on integrating associated nations of Central and Eastern Europe with the EU internal market that was approved at the EU Council meeting in Cannes, 1995;

- Code of Conduct for Business Taxation;

- Council Directives in various years covering avoidance of double taxation, taxing savings, dividends, shares and entities operating in various member states.

\subsection{Rules regarding the avoidance of double taxation of income and wealth}

Tax problems for individuals who change their place of work and residence are not new, especially when we consider the notion of avoiding double taxation of income. Currently, the majority of nations have signed bilateral agreements on avoiding double taxation, based on early work by the OECD that had developed a "model agreement" intended to ease negotiations, with the newest model proposed in 1996. 
Only the Nordic Treaty between Denmark, Finland, Sweden, Iceland and Norway is not bilateral in nature and should be seen as a precursor of things to come in providing precise multinational solutions. The OECD Convention is still the prime example and has affected the development of similar policies in the Union. It predicts three possibilities for taxing income gained in different nations:

1. Taxing the entire income or wealth created in a different country.

2. Nations share the income from taxation in varying proportions depending on the subject of taxation (dividends, interest on savings, etc).

3. Nations, on whose territory the income or wealth was created, cannot tax them (sale of shares, license fees, scholarships).

\subsection{Rules regarding capital income tax}

The current investor-friendly culture assures that increasing numbers of EU citizens invest their money in multiple companies and expect to gain a profit that is later taxed. The broad rules for taxing dividends and profits from business operations of multinational businesses are defined by EU directives. Yet, individual countries, have certain freedom in this respect, for example by differing in the way such taxes are collected. Two methods exist: taxing the profits of the company and foregoing taxing shareholders and partners or allowing the company not to pay a tax on the paid-out profit and the tax obligation rests on shareholders and partners. Countries differ in the preferred method (Vlachy 2008: 649-661).

\subsection{Rules regarding taxing profits from savings}

Harmonising the taxation of savings residing in bank accounts has focused on preventing any restrictions to the flow of capital between member states that could be imposed by national tax laws. The key to such harmonisation is therefore not to enforce a single tax rate for all states: every state is free to set its own taxes (level, differentiation) and profits from savings can be separated from other personal income and taxed with a separate rate or included in total incomes.

\section{Taxing individual incomes for those not conducting business activities}

The main characteristic of direct taxation is the small extent to which it has been normatively harmonised.
Since direct taxes are seen to have less of a negative impact on the operations of the Common Market, therefore work on their harmonisation has begun late and has not progressed as far as the work done on indirect taxes. Nations have been left to define their own internal policies but are required to assure fair treatment to local and international entities. The analysis of individual income taxation in EU states, the direction of its evolution and the future of tax policy allows for the formulation of two arguments: the extensive difficulties of harmonising the construction of personal income tax and a progression of "quiet harmonisation" (paralegal). The arguments presented below confirm the proposed arguments.

EU member state tax systems created since the Second World War, were strongly influenced by the ideas of John Maynard Keynes who moved away from the notion of tax neutrality and placing specific parafiscal functions on the tax system. Taxation of personal income is one of the most fundamental techniques for redistributing income, allowing for the realisation of principles of equality and justice and taxing of "pure income" (all three rules are expected of every tax system in the union), and stimulating desirable behaviours in the spheres of production and consumption. As such direct taxes have a much different impact upon the division of income and wealth than indirect taxes. Income taxes possess an "inbuilt stabilising flexibility", e.g. in times of recession they inhibit the fall of global demand and in times of growth, slow down its expansion. Progressive income taxation of individuals leads to a much faster fall in governmental revenues due to a fall in the citizens' income. As such, despite declaring intended tax system neutrality, EU member states allow parafiscal functions to affect the construction of the PIT framework, which in turn makes harmonisation extremely difficult.

The current belief is that differentiation in setting the rules governing direct taxation poses a small challenge to the functioning of the Common Market. It is based on:

1. Income taxes in their pure form do not stimulate the propensity to save and invest. Income taxes impact both the saved part of income as well as the spent. To stimulate saving and/or spending it is necessary to introduce allowable deductions and tax credits that would be obtainable upon increasing existing savings or investments or undertaking them. 

e.g. any activity in this are will have an impact on the political balance of the nation. PIT setting is an important and valuable tool in maintaining relations with voters.

2. PIT harmonisation is not an important factor in the evolution of the Common Market. It is neutral to internal trade and does not affect intra-EU competition and as such will not become a European priority for some time.

3. PIT taxes mainly incomes from work and retirement and the level of taxation does not increase intra-EU migration (although in the long-run this may change).

4. In EU member states, social support systems are funded from different sources: taxpayer contributions, direct funding from the state budget (social security contributions are then contained within standard taxes, e.g. Denmark) and as they form part of the total "tax wedge", their harmonisation will be even more difficult (while exerting sizeable influence on the PIT system).

5. EU member states possess different systems of labour remuneration and shaping of citizen income levels, different methodologies of designing tax progression. Therefore even creating a holistic and long-term understanding of existing complexities will be difficult.

\section{Conclusions}

Harmonisation in general is a difficult challenge, and any debate about harmonising PIT systems brings out major counterarguments:

1. Further loss of sovereignty in national financial policies, which will inhibit the state's ability to affect economic processes and (especially) social ones. Harmonisation of the rules for calculating the basis for taxation and the acceptance of unified rates would mean the transfer of tax-setting prerogatives to a trans-national institution: the EU. In such a situation, each nation must conduct its own analysis of costs and benefits (of transferring those competencies versus their retention).

2. Different social models and retirement systems, when combined with varied degrees of PIT integration with retirement contributions, determine various financial needs of the state, therefore harmonisation would have to reach far beyond "mere" PIT systems.
3. Historical, cultural, social factors that have shaped national tax systems enforce claims that path-dependent process will be difficult to reverse.

4. Competitive inequality between taxpayers who operate in one market and those that function in multiple EU member states. Depending on their primary country of residence it can be an advantage to pay taxes elsewhere (when the other nation's tax regime is friendlier, e.g. for Poles employed and taxed in the UK) or a disadvantage (when British taxpayers operating in Poland or Poles earning in the UK are subject to Polish taxation).

Not withstanding abovementioned criticisms, the following predictions can me made regarding income tax (primarily PIT) harmonisation across the European Union:

1. Harmonisation of direct taxes is unavoidable, but it will be a long-term process and will affect CIT before PIT (reducing complexity of trans-border business operations will be a priority compared to easing the life of individual taxpayers). It is likely that the global economic crisis (2008-2009?) will negatively impact the speed of any harmonisation as governments focus on surviving the difficult period and, since research suggests that speedy harmonisation negatively affects economic growth, governments will remain weary of such processes, keen to defend any possible economic growth (and thus their own positions) (Kopits, 1992).

2. The current process of direct tax harmonisation is in an early stage of progress due to existing extensive national variations. Forces promoting reform are more economic and include the unified market, common currency, need to increase competitiveness. Opposing forces are more ideological and focus on the dangers of sacrificing fiscal competencies, especially that these powers will be handed over to a supranational body. The need for unanimous voting when backed by the complexity of current tax policies are the main causes for a slow harmonisation process (rationality of pure tax-related arguments comes in conflict with local political rationality).

3. At the very least, it is crucial to assure the enforcement and optimisation of regulations covering the avoidance of double taxation, both personal (PIT) and business (CIT). The need for speedy resolutions stems from the growth and expansion of 



\section{References}

1. Agra Facts nr 05-07, 19.10.2007.Alworth J., Arachi G., Taxation Policy in EMU, Economia della Tassatzione, Pavia University 2008.

2. Baldwin R., Krugman P., Agglomeration, Integration and Tax Harmonisation, "European Economic Review" vol. 48, 2004.

3. Bolkstein F., Toward an internal market without tax obstacles, Speech at European Commission on company taxation in the EU, Brussels, 29 April 2002.

4. Caroll,R., Holtz-Eakin M. (et al), Personal Income Taxes and the growth of small firms, NBER, "Working Paper" vol. 7980, 2000.

5. Davidson S., Tax Competition. Much To Do About Very Little, The Center for Independent Studies Policy Monograph No. 78, 2007.

6. European Tax Handbook 2008, International Bureau of Fiscal Documentation, Amsterdam 2009.

7. Global Individual Tax Handbook 2007, International Bureau of Fiscal Documentation, Global Tax Series, Amsterdam 2008.

8. Individual Income Tax Rate Survey, KMPG, 2008.

9. James S., Nobes Ch., The Economics of Taxation, Prentice Hall, New York 1995.

10. Kopits G. (ed.), Tax harmonization in the European Community: policy issues and analysis, IMF “Occasional Paper”, vol. 94, 1992.

11. Kucharek W., Podatek europejski. Czy może być źródłem dochodów budżetu UE?, "Biuletyn Skarbowy", nr 2, 2007.

12. Meghir C., Philips D., Labour supply and taxes, The Institute for Fiscal Studies, "Working Paper" No. 4, 2008.

13. Mintz J., Corporate Tax Harmonization in Europe: It's All About Compliance, "International Tax and Public Finance", No. 11, 2004.

14. Oates W.E., Fiscal Competition or Harmonization? Some Reflections, "National Tax Journal", No. 54, 2001.

15. OECD, Fundamental Reform of Personal Income Tax, “OECD Tax Policy Studies”, No. 13, 2006.

16. Sabrinova K.P., Buttrick S., Duncan D., Global reform of Personal Income taxation, 1981-2005. Evidence from 189 Countries, Andrew Young School of Policy Studies, "Working Paper" No. 8, 2008.
17. Szeląg K., Jednolita polityka budżetowa w strefie euro - realna wizja czy utopia?, "Bank i Kredyt", nr 11-12, 2003.

18. Epstein R., Johnson J., Uneven Integration: Economic and Monetary Union in Central and Eastern Europe, Journal of Common Market Studies, vol. 48, 2010.

19. Tanzii V., Zee H.H., Consequences of the Economic and Monetary Union for the coordination of tax system in the European Union: lessons from the US experience, "IMF Working Paper", No. 115, 1998.

20. Taxation Trends in the European Union. Data for the EU Member States and Norway, European Communities, Luxembourg 2008.

21. Vlachy J., Assessing Tax Asymmetries and the Incentive to Incorporate, Journal of Economics, vol. 56, 2008.

22. Zee H.H., Personal Income Tax Reform: Concepts, Issues and Comparative Country Developments, IMF Working Paper, No. 05, 2005.

23. Zodrow G.R., Tax Competition and Tax Coordination in the European Union, "International Tax and Public Finance", No. 10, 2003.

\section{Notes}

1. The term "tax dumping" was popularised by Chancellor Gerhard Schroeder in 2004, when he challenged new EU member states and their tax reforms that were aimed, as Schroeder claimed, at affecting fair competition policies in the Union by offering good operating conditions for companies form the "old" Europe.

2. On 26th May 2004, Ministers of Finance from Germany and France, worried that their countries would suffer the most from tax-benefit-seeking company migration, proposed the first unification of corporate (CIT) tax rates: minimal rates, formalising the methods of calculating incomes, profits, defining expenses.

3. Unlimited tax duty applies to those residing in a country for more than 183 days of a tax year, while limited tax duty is applied to those who spend less than 183 days.

4. Jan Vlachy presents very interesting analysis of a single-period option-based model to analyze the net value of business income under uncertainty, focus- 